\title{
A NEW SPECIES OF EURYSTYLES (ORCHIDACEAE) IS EXPOSED BY A FIERCE HURRICANE IN PUERTO RICO
}

\author{
JAMES D. ACKERMAN ${ }^{1,3} \&$ LUIS OrTiz JORDAN ${ }^{2}$ \\ ${ }^{1}$ Department of Biology, University of Puerto Rico, 17 Avenida Universidad Suite 1701, \\ San Juan, Puerto Rico 00925-2537, U.S.A. \\ ${ }^{2} 815$ Promenade Way, Apt 204, Jupiter, FL 34458, U.S.A. \\ ${ }^{3}$ Author for correspondence: ackerman.upr@gmail.com
}

\begin{abstract}
A new species of Eurystyles (Orchidaceae: Orchidoideae, Cranichideae, Spiranthinae) is proposed, E. luisortizii Ackerman $s p$. nov., which is most similar to E. ananassocomos (Rchb.f.) Schltr. from which it differs by a suite of floral traits. This species represents the first confirmed record of the genus for the island of Puerto Rico, bringing the Eurystyles species count for the West Indies to four.

Resumen. Se propone una nueva especie de Eurystyles (Orchidaceae: Orchidoideae, Cranichideae, Spiranthinae), E. luisortizii Ackerman sp. nov., la cual es similar a E. ananassocomos (Rchb.f.) Schltr., de la que se diferencia por un conjunto de rasgos florales. Esta especie representa el primer registro confirmado del género para la isla de Puerto Rico, lo que eleva el recuento de especies de Eurystyles para las Indias Occidentales a cuatro.
\end{abstract}

Keywords/Palabras clave: Cranichideae, Flora de Puerto Rico, Orchidoideae, orquídeas de las Indias Occidentales, Puerto Rico flora, Spiranthinae, West Indies orchids

Introduction. The genus Eurystyles Wawra (Orchidaceae: Orchidoideae: Cranichideae; Spiranthinae) comprises of approximately 24 species and is widely distributed from Mexico, Greater Antilles, Central America to South America (Salazar et al. 2018, Bogarín 2020). Recently, three species have been reported for the West Indies (Ackerman et al. 2014). While no previous specimens of Eurystyles from Puerto Rico are known, there has been an unpublished report of the E. annassacomos (Rchb.f.) Schltr. from the early 1970s. Professor Roy Woodbury of the University of Puerto Rico, Río Piedras, found a specimen on Cerro La Santa of the Sierra de Cayey, displayed it at a local orchid show but did not make a specimen of it. Unfortunately, the plant perished, and the locality was soon cleared and flattened to construct communication towers (Woodbury pers. com. 1981). Subsequent searches by Woodbury and others (including JDA) proved unsuccessful (Ackerman 1995). While Woodbury was a very good floristic botanist with a special interest in orchids, his determination that the plant was E. annassacomos may be doubtful. Until Donald D. Dod $(1977,1978)$ studied the genus in Hispaniola, all Eurystyles in the West Indies were regarded as E. annassacomos. We now know that there are at least three species in the Greater Antilles, and E. annassacomos is verified for only Jamaica (the type locality) and Hispaniola (Ackerman et al. 2014).

For nearly five decades, no new sightings of Eurystyles in Puerto Rico had been made until two months after the devastating September 2017 Hurricane María, a category four storm with sustained winds $250 \mathrm{~km} / \mathrm{h}$. One of us (Luis) was hiking on a ridge above Lago Garzas in the municipality of Adjuntas near his family's coffee farm. While walking the trail and climbing over and around broken and fallen tree trunks and branches, he found several plants of Eurystyles on a tree trunk. Luis looked among the numerous broken trees in the area but did not find other plants of $\mathrm{Eu}$ rystyles. Then in the next season (December 2018), with Luis no longer on the island, JDA located the trail using Luis's geographical coordinates. Unfortunately, the forest was so damaged that the trail was impassable due to fallen trees, massive invasive grasses, and smothering vines that had grown up since the storm.

Upon examination of the specimens that Luis collected, we concluded that they were similar to the specimen of E. annassacomos that Bobbi Angell illustrated for the Orchid Flora of the Greater Antilles, but differed by having slightly smaller flowers, a lip lack- 


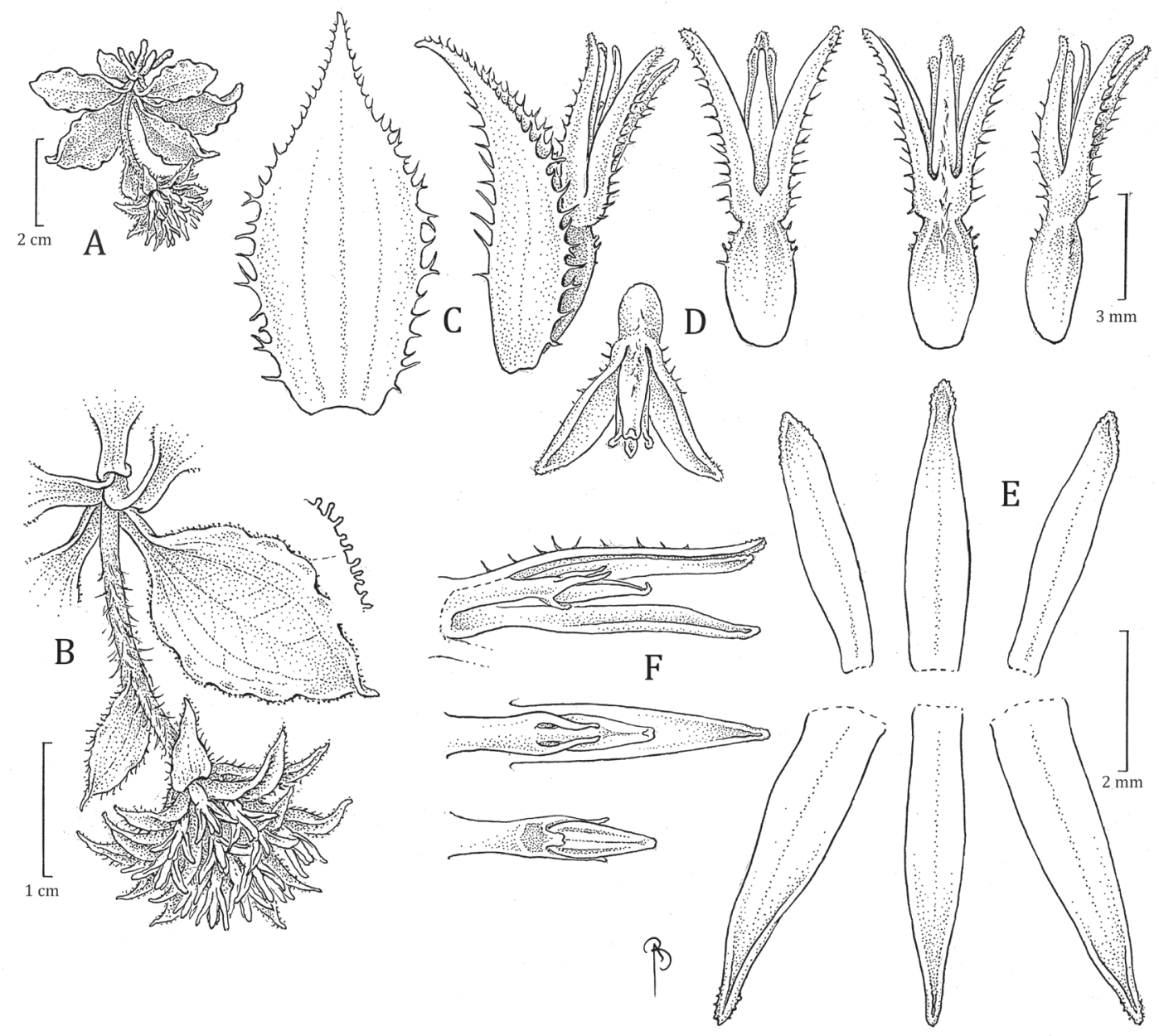

Figure 1. Eurystyles luisortizii Ackerman. A. Plant habit. B. Inflorescence and detail of leaf margin. C. Floral bract. D. Flower, left to right: front, ventral, dorsal and lateral views. E. Perianth, clockwise from upper left: petal, dorsal sepal, petal, lateral sepal, labellum, lateral sepal. F. Dissected flower, top to bottom: lateral view with one sepal and petal removed exposing the column; dorsal view of column with labellum; ventral view of column. Based on pickled material of holotype collection, L. Ortiz Jordan s.n. (US, UPRRP). Illustrated by Bobbi Angell.

ing basal auricles, and being single-veined, rather than having small basal auricles and 3 veins; and by having simple, erect staminodes, not bifurcated and curled.

We propose to designate these plants as representing a new species since flower morphology is both consistent and easily distinguishable from other Eurystyles species, especially those from the West Indies, which have been studied in detail (Ackerman et al. 2014). Bobbi Angell illustrated both the specimen from the Dominican Republic, which was published in Orchid Flora of the Greater Antilles (Fig. 51 in Ackerman et al. 2014), and the Ortiz specimens examined here (Fig. 1). We can only speculate whether Woodbury collected the same thing five decades ago on Cerro La Santa, which is some $75 \mathrm{~km}$ east of the Adjuntas type locality.

\section{TAXONOMIC TREATMENT}

Eurystyles luisortizii Ackerman, sp. nov. (Fig. 1-3.)

TYPE: Puerto Rico. Municipality of Adjuntas: above Lago Garzas, trail from Rd 518 to bridge across the lake, $18^{\circ} 08^{\prime} 2.43^{\prime \prime} \mathrm{N}, 66^{\circ} 44^{\prime} 23.43^{\prime \prime} \mathrm{W}$, wet secondary 

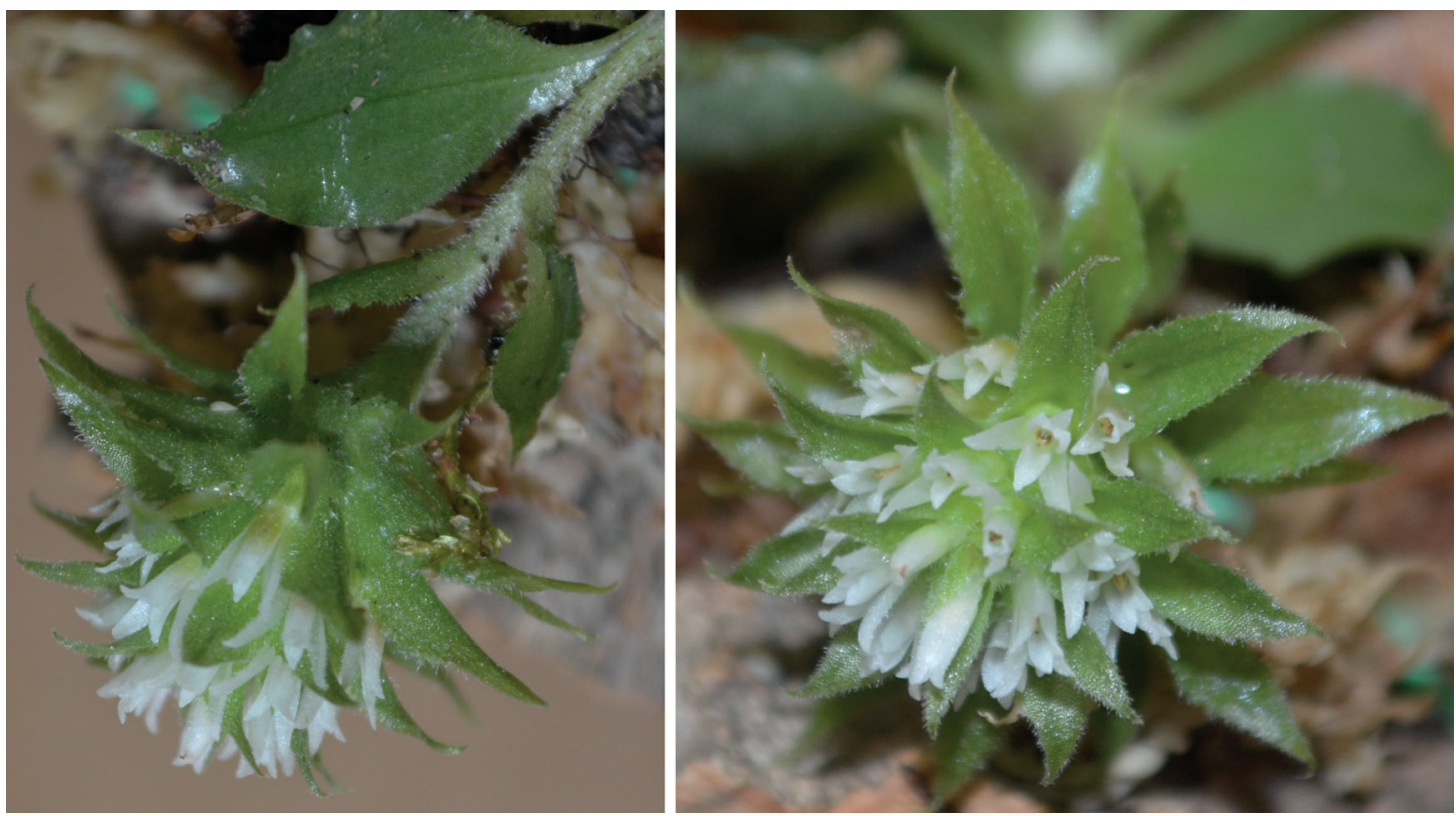

FiguRE 2. Eurystyles luisortizii Ackerman. Inflorescence, side view; inflorescence head-on. Photographed by Jonathan López, reproduced with permission.

forest, elev. $783 \mathrm{~m}$, originally collected in November 2017, flowered in cultivation 28 November 2018, L. Ortiz Jordan s.n. (holotype: US; isotype: UPRRP).

Diagnosis: Eurystyles luisortizii Ackerman is vegetatively similar to Eurystyles annassacomos (Rchb.f.) Schltr. but differs florally by having a narrower lip (0.6-0.8 mm vs. 1.5-2.0 mm), a single-veined lip vs. 3-veined, lip lacking basal auricles vs. being auriculate, and the staminodes simple and erect $v s$. bifurcated and curved (Fig. 1).

An epiphytic, bromeliad-like, pendent, caespitose herb up to $4 \mathrm{~cm}$ long including the inflorescence. Roots few, short, fleshy 6-9 mm long, 2.0-2.5 $\mathrm{mm}$ in diameter. Stem covered by leaf bases, ca.3-4 mm long. Leaves up to 7 , rosulate; petioles from an expanded, sheathing base, broad, canaliculate, $c a .4 .5 \times 2.0 \mathrm{~mm}$; blades waxy, shiny grayish-green, soft-textured, ovateelliptical, cuneate, acute with an apiculate tip, with five main arching veins, the mid vein pinnate, 18-25 $\times 12.5-23.0 \mathrm{~mm}$, margins undulate, pectinate-ciliate. Inflorescences terminal, solitary, pendulous; peduncles terete, densely ciliate, about 16-20 mm long, $1 \mathrm{~mm}$ diameter; bracts foliaceous 1-2, elliptical, acuminate, denticulate-ciliate from broad-based hairs, ca. $10.0 \times$
$4.5 \mathrm{~mm}$; racemes subcapitate, congested, with 10-20 flowers opened more or less simultaneously; floral bracts slightly exceeding the length of the flowers, foliaceous, elliptical, acuminate when spread, funnel shaped enveloping flower, margins pubescent, hairs with a broad base, denticulate-ciliate, 3.7-4.0 × 1.6$2.0 \mathrm{~mm}$. Flowers inconspicuous, non-resupinate, tubular, sepals, petals, and lip white. Ovary green, sessile, obovoid, glabrous below, sparsely ciliate above near junction with perianth, somewhat flattened-obovoid, 3.0-3.4 × 1.5-1.7 mm. Dorsal sepal lanceolate, minutely warty at apex, otherwise glabrous, 4.0-4.5 × 1 $\mathrm{mm}$. Lateral sepals slightly gibbous and fused at the base for $0.5 \mathrm{~mm}$, dorsally hirsute along mid vein, canaliculate, lanceolate, acuminate, dorsally keeled at apex, 4-5 $\times 0.8 \mathrm{~mm}$ when spread. Petals narrowly oblanceolate, acute-obtuse, adhering to the dorsal sepal, $4.0 \times$ $0.5 \mathrm{~mm}$. Lip narrowly elliptic, lacking basal auricles, apex acuminate, canaliculate, slightly thicker than the rest of the lip and minutely warty, 4.0-4.5 × 0.6-0.8 $\mathrm{mm}$. Column subterete, glabrous, 2.8-3.0 mm long, rostellum triangular-ovate, acuminate, $0.5 \times 0.2-0.3$ $\mathrm{mm}$ at base, staminodes aciculate, erect, $1.1 \mathrm{~mm}$ long anther subsessile, $1.5 \mathrm{~mm}$ long, pollinia 2, clavate, mealy, $1.1 \mathrm{~mm}$ long. Fruits not seen; post-anthesis 


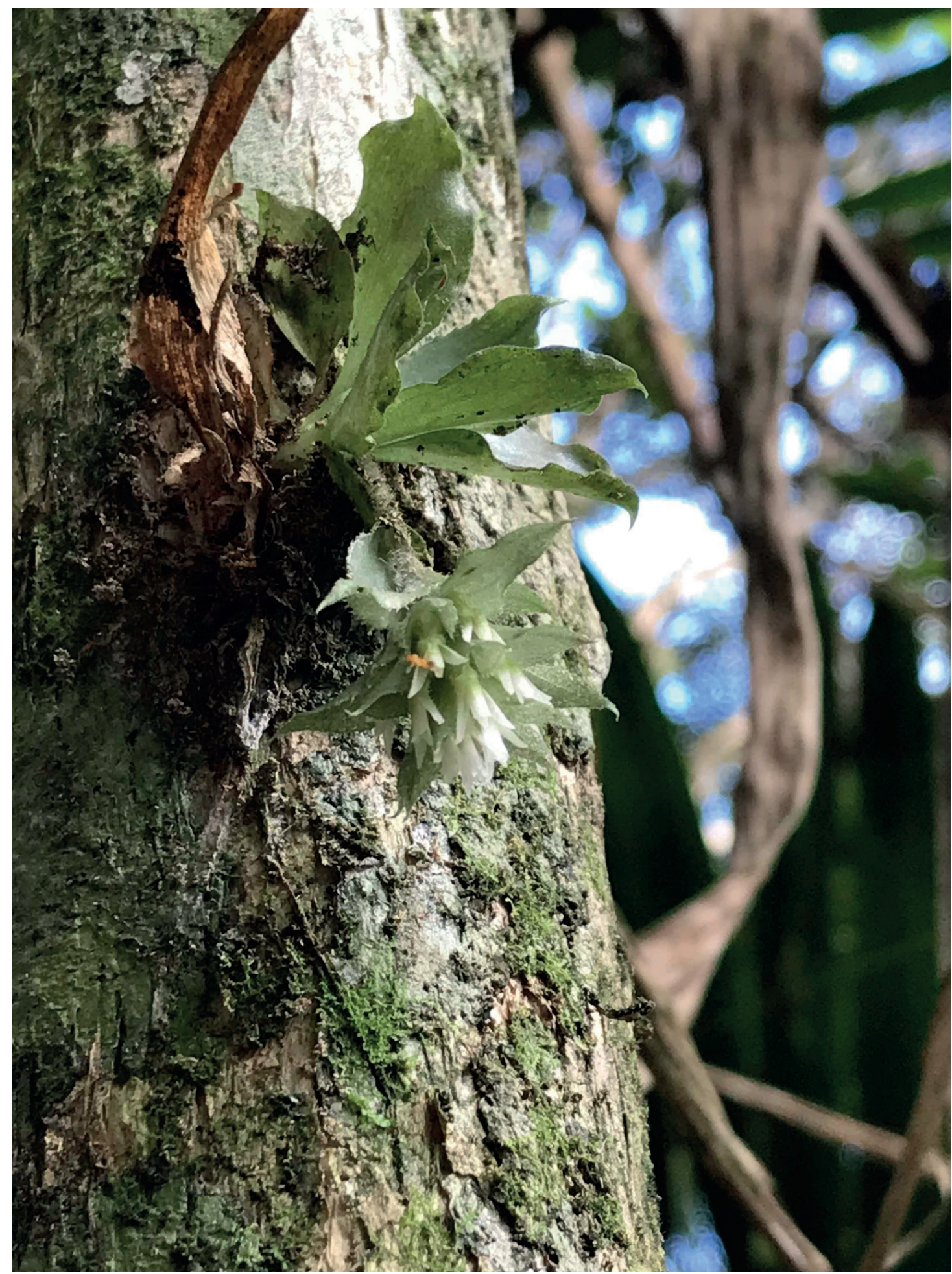

Figure 3. Eurystyles luisortizii Ackerman. Plant habit in situ. Photographed by Luis Ortiz Jordan. 
swollen ovaries $c a .4 \mathrm{~mm}$ long, $2.5 \mathrm{~mm}$ in diameter. Seeds not seen. Description based on three plants.

Etymology: The specific epithet is named for the discoverer, Luis Ortiz Jordan, an avid native orchid enthusiast. He has a Master of Science in Environmental Management and works as an environmental scientist in Florida, USA.

Phenology: Flowers appear from November to February. Fruiting was not observed. New shoots begin to form as leaves senesce and flowering ends.

Reproductive Biology: The ovaries of all flowers in the two inflorescences we have studied were swelling, yet they all had intact pollinaria, suggesting apomixis or autogamy may occur, a phenomenon that appears to be common in the genus (Szlachetko 1992). However, despite the plants doing very well in cultivation since late 2017, none of them have produced mature fruits, which of course may mean they require pollinator-mediated pollination. In the 2020-2021 flowering season, we self-pollinated five flowers. The ovaries became swollen, but no seeds formed so the flowers may be self-incompatible. If reproduction is verified to be pollinator-dependent, then attraction is likely based on deception. We carefully dissected flowers to detect nectar, but no free liquid was evident. Vigorous plants in cultivation produce scentless flowers to the human nose and last 4-6 weeks unpollinated. In cultivation under insect-free conditions, ovaries appear to swell somewhat, but fruits do not mature.

Distribution AND ECOLOGY: Known only from the type locality, where they grow epiphytically on tree trunks in wet tropical montane forests. If the Eurystyles previously reported by Professor Woodbury was E. luisortizii, then elevational range is up to $900 \mathrm{~m}$.

Conservation status: We think that the situation for Eurystyles luisortizii is dire. Only three plants were found $2 \mathrm{~m}$ up on the trunk of a severely damaged tree, the consequence of Hurricane María. Most of the forest canopy was destroyed on ridges and those slopes that faced the brunt of the storm. Winds were so strong that those trees left standing (primarily palms) had the appearance of being power-washed. Epiphytes were ripped off or fell with their hosts, as has happened with other strong hurricanes (Migenis \& Ackerman 1993). Nevertheless, small pockets of forest were somewhat intact, and until the forest recovers sufficiently to make detailed surveys of the area, we regard the conservation status of E. luisortizii to be data-deficient (DD) but likely endangered.

Key to the SPECiES of EuRYSTYLES OF the West IndiEs (MODIFIED FROM ACKERMAN ET AL. 2014)

1. Sepals distinctly inflated basally; high elevations $(>1500 \mathrm{~m})$

E. alticola

1a. Sepals not inflated basally; lower elevations $(<1000 \mathrm{~m})$

2. Labellum pandurate with a distinct suborbicular apex

E. domingensis

2a. Labellum narrowly elliptic to oblanceolate, with a keel-like acuminate apex

3. Labellum basally auriculate, 3-veined; staminodes bifid, the dorsal lobe incurved over the anther

\section{E. ananassocomos}

3a. Labellum lacking auricles, 1-veined; staminodes simple, straight

E. luisortizii

Acknowledgements. We thank Jonathan López Colón for permission to use his photographs and Bobbi Angell for permission to use her elegant illustrations. Unfortunately, the New York Botanical Garden Press did not respond to our request to use Bobbi's previously published illustration of E. ananassocomos in Orchid flora of the Greater Antilles (Ackerman et al. 2014). Plant collection was made under the auspices of the Departamento de Recursos Naturales y Ambientales, Gobierno de Puerto Rico, permiso científico: 2017-IC-056.

\section{LitERATURE CITED}

Ackerman, J. D. (1995). An orchid flora of Puerto Rico and the Virgin Islands. Memoirs of the New York Botanical Garden, $73,1-203$.

Ackerman, J. D. \& Collaborators (2014). The orchid flora of the Greater Antilles. Memoirs of the New York Botanical Garden, 109, 1-625.

Bogarín, D. (2020). A new species of Eurystyles (Orchidaceae: Spiranthinae) from Costa Rica. Blumea, 65, 65-68. doi: 
10.3767/blumea.2020.65.01.07

Dod, D. D. (1977). Orquídeas Dominicanas nuevas. II. Moscosoa, 1(2), 39-54.

Dod, D. D. (1978). Orquídeas Dominicanas nuevas. III. Moscosoa, 1(3), 49-63.

Migenis, L. E. \& Ackerman, J. D. (1993). Orchid-phorophyte relationships in a forest watershed in Puerto Rico. Journal of Tropical Ecology, 9, 231-240. doi: 10.2307/2559295

Salazar, G. A., Batista, J. A. N., Cabrera, L. I., van den Berg, C., Whitten, W. M., Smidt, E. C., Busatto, C. R., Singer, R. B., Gerlach, G., Jiménez-Machorro, R., Radins, J. A., Insaurralde, I. S., Guimarães, L. R. S., de Barros, F., Tobar, F., Linares, J. L., Mújica, E., Dressler, R. L., Blanco, M. A., Hágsater, E., \& Chase, M. W. (2018). Phylogenetic systematics of subtribe Spiranthinae (Orchidaceae: Orchidoideae: Cranichideae) based on nuclear and plastid DNA sequences of a nearly complete generic sample. Botanical Journal of the Linnean Society, 186, 273-303. doi:10.1093/botlinnean/ box096

Szlachetko, D. L. (1992). Notes on Eurystyles (Orchidaceae), with a description of a new species from Mesoamerica. Fragmenta Floristica et Geobotanica, 37, 13-19. 